\title{
DEATH DUE TO CARDIAC ANGIOSARCOMA: AUTOPSY CASE REPORT
}

\author{
F. Eren, N.T. Inanır, M.S. Gurses, B. Eren*, U.N. Gundogmus, B. Ioan \\ TOKAT GAZIOSMANPASA UNIVERSITY, TOKAT, TURKEY
}

\begin{abstract}
Background. Primary tumors of the heart are rarely detected at autopsy, especially angiosarcomas which are primary malignant one.

Objective. We presented autopsy case of cardic angiosarcoma with morphologic findings.

Methods. We described adult man died in emergency service of the hospital.

Results. Reported case was 33 year-old-man who was died in emergency service of hospital where he was taken when he was ill after leaving home. According the prosecution documents, and the expressions of family, it was reported that he had a heart disease; his symptoms repeated 3 day ago before he died, he thought to attend the Cardiology Clinic due to his symptoms. At autopsy on macroscopic internal examination, mass with rough surface in the right atrium, hematoma at the posterior of the right atrium, blood in the pericardia, nodular lesions in hemorrhagic appearance in the sections of lung, liver and spleen were detected. In histopathologic examination; in the heart angiosarcioma as primary malign heart tumor and metastatic masses in the liver, spleen and lung were detected.
\end{abstract}

Conclusions. We aimed to discuss cardiac angiosarcoma case with autopsy and histopathologic findings in the aspect of medico legal literature.

KEYWORDS: Angiosarcomas; heart; metastatic tumors; autopsy.

\section{Introduction}

Primary tumors of heart are rare and they are revealed with prevalence between 0.0017 and 0.19 percent at autopsy [1]. While 75 percent of primary tumors of heart are benign, 25 percent are malign tumors [2]. Angiosarcomas, which are 35-40 percent of primary malign tumors, are the most common $[3,4]$. Primary tumors are mostly developing in the right atrium and pericardium [5]. Diagnosis of patients is delayed until tumors become untreatable and many systemic metastases are present $[4,6]$. The research is aimed to study the autopsy and histopathologic findings of the case in medical and legal aspect.

\section{Case Report}

The case involves a 33 year-old-man reported to pass away in the emergency department of hospital, where he was admitted, when he got ill after leaving home. In the analysis of the prosecution documents and according to the words of family members, it was reported that he had a heart disease; chest pain repeated 3 days before he died, he thought to attend the Cardiology Clinic due to the symptoms. In

*Corresponding author: Bulent Eren, MD, Pathologist, Forensic Medicine Specialist, Associate Professor, Tokat Gaziosmanpaşa University School of Medicine, Department of Forensic Medicine, Kaleardı Mahallesi, 60030 Tokat, Turkey. Phone: +903562149444 / 7206,

e-mail:drbulenteren@gmail.com autopsy external examination, there were no pathologic findings, except for ecchymosis due to catheters on the dorsum of the right and left hands and left inguinal line. In internal examination revealed mass on the rough surface of the right atrium (Fig. 1), hematoma at the posterior of the right atrium, $500 \mathrm{cc}$ free blood in pericardia, inhemorrhagic nodular lesions in the sections of lungs, liver and spleen (Fig. 2).

Histopathologically, in sections of heart, tumoral proliferation of atypical cells, which had a high mitotic index and spindle-oval nucleus and infiltrates between myocardial fibers, were observed. There was diffuse hemorrhagic necrosis in the myocardial muscle fibers around tumoral tissue. In lungs, a group of atypical spindle tumoral cells, which had thin-walled vessels and were separated from lung parenchyma with irregular borders, were observed. In liver, many extravasated erythrocytes and tumoral lesions consisting of spindle cells were evidenced. In spleen, many extravasated erythrocytes and tumoral lesions consisting of spindle cells were present. The histopathologic examinationrevealed angiosarcioma in the heart as primary malign heart tumor and metastatic tumors in the liver, spleen and lung. The toxicological investigations were absolutely negative. The cause of death was reported as cardiac angiosarcoma. 


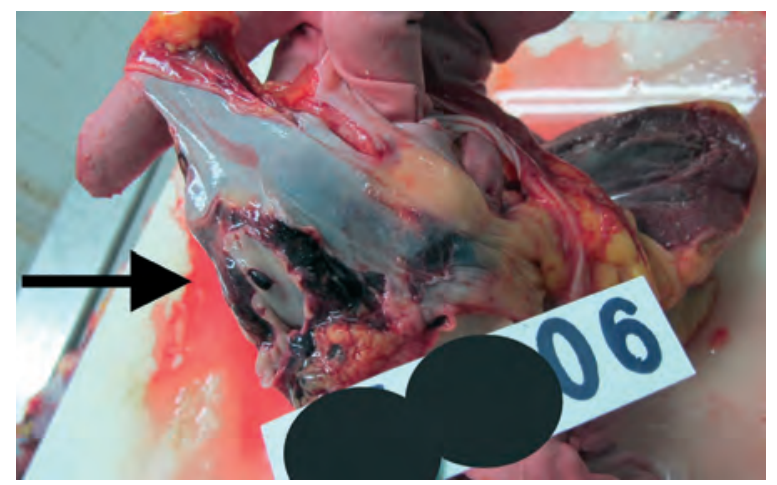

Fig. 1. The arrow shows the mass on the rough surface of the right atrium (arrow).

\section{Discussion}

Primary tumors of the heart are rare and are revealed with prevalence between 0.0017 and 0.19 percent at autopsy [1]. Approximately three-quarters of primary heart tumors are benign with atrial myxomas comprising threequarters of them [2]. Angiosarcoma is the most common of malignant cardiac tumors [7]. Cardiac angiosarcomas can be found in right atrium, left atrium, pulmonary artery, but most commonly in the right atrium [8], as in our case.

Angiosarcoma is established to be as twofold in men, typically between the third and fifth decade $[4,10]$ and our case is consistent with the literature. A study reported that a small series of heart sarcomas were subjected to a specific molecular study that proved the presence of K-ras mutations at codon 13 [11]. In human study mutation of the p53 tumor suppressor gene was present in cardiac angiosarcomas [12]. Cardiac sarcomas are rare but lethal disease. It is associated with a poor prognosis and median survival time from 1 to 81 months [6]. Angiosarcoma is associated with a high rate of hematogenous metastases, most of this tumors produce systemic metastases at the time of its detection, most commonly to the lungs, in addition to the liver, brain, adrenal glands, and bone $[6,5,13]$. In our case lung, liver metastases were present compliant with the literature. In addition, in our case there were splenic metastasis different from the literature.

Patients often have non-specific symptoms. So, it is difficult to diagnose cardiac angiosarcoma. Initial findings may include chest pain, dyspnea, fatigue, cough, heart murmur of unclear mechanisms, superior vena cava syndrome, constitutional symptoms, pericardial effusion, pericardial tamponade, arrhythmias, non-specific ST changes on ECG $[6,13,14]$ Echocardiography, magnetic resonance image

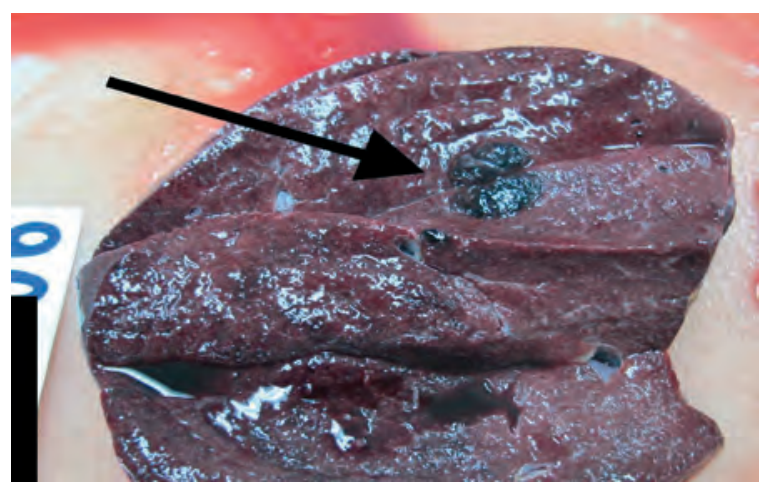

Fig. 2. The arrow shows hemorrhagic nodular metastatic lesions in the sections of spleen (arrow).

(MRI) and computed tomography (CT) are used for diagnosis and systematic evaluation of cardiac angiosarcoma [15, 16, 17]. Echocardiography, transesophageal or transthoracic, is the main tool for describing the localization and size of a mass [18]. There is no specific tissue density that is why the diagnosis of angiosarcoma is challenging. The histological examination of fluid taken by pericardiosentesis, revealed malignant cells. The definitive diagnosis of angiosarcoma is biopsy $[15,16]$. Several studies established that infiltration of the myocardium by spindle cells, hyperchromatic nuclei, mitotic figures in various stages, giant cells, including tumor necrosis and hemorrhage in common areas, negative for cytokeratin, vimentin and FVIII were revealed as positive staining by histopathological examination [6, $15,16]$. Ge et al. reported that the tumor cells in cardiac angiosarcomas were strongly positive for CD31, CD34, FLI-1, and WT-1 but negative for $A E 1 / 3, D 2-40$, human herpesvirus 8 , and epidermal growth factor receptor by immunohistochemical method [6].

The rareness of this disease limits gaining experience for adequate treatment. The therapeutic approach for primary cardiac angiosarcoma is surgery, chemotherapy and radiotherapy, alone or in combination. The initial treatment is surgery $[6,19]$.

\section{Conclusions}

Primary tumors of the heart are mostly originating in the right atrium and rarely observed at autopsy. Angiosarcomas are most commonly seen primary malign tumors. We discussed cardiac angiosarcoma case with autopsy and histopathologic findings in the aspect of medico legal literature.

\section{Conflict of interest}

The authors declare no conflict of interest. 


\section{РАПТОВА СМЕРТЬ ВНАСЛІДОК АНГІОСАРКОМИ СЕРЦЯ: РЕЗУЛЬТАТИ АУТОПСІї}

F. Eren, N. Turkmen, I.M. Serdar Gurses, B. Eren, U.N. GUndogmus, B. Ioan TOKAT GAZIOSMANPASA UNIVERSITY, TOKAT, TURKEY

Вступ. Первинні пухлини серця вкрай рідко зустрічаються при аутопсіях, особливо ангіосаркоми, які належать до злоякісних новоутворів.

мета роботи привернути увагу та ознайомити широке коло читачів з результатами аутопсії та морфологічними даними при ангіосаркомі серия.

Методи. Описано та проаналізовано результати аутопсії дорослого чоловіка, який помер у відділенні невідкладної допомоги.

Клінічний випадок. 33-річний чоловік помер у відділенні невідкладної допомоги, куди був доставлений з дому. Зі слів рідних у нього була хвороба серця, а перед смертю протягом трьох днів турбував біль у серці, з приводу якого він планував звернутися улікарню. При аутопсії виявлено новоутвір з шорсткою поверхнею у правому передсерді, гематому на задній стінці правого передсердя, 500 мл крові у перикарді, також було виявлено вузлові утвори при розтині легень, печінки та селезінки. За результатами гістологічного дослідження встановлено діагноз ангіосаркоми серця, як первинної пухлини, з метастазами у легені, печінку та селезінку.

Висновки. Описано рідкісний клінічний випадок ангіосаркоми серця, виявлений посмертно на aymonciï.

КЛЮЧОВІ СЛОВА: ангіосаркома; серце; метастази; ауатопсія.

\section{Information about the authors}

Filiz Eren - MD,Pathologist Specialist, Council of Forensic Medicine of Turkey, Bursa Morgue Department, Bursa, Turkey.

ORCID 0000-0003-1542-8694, e-mail: filizeren2010@gmail.com

Nursel Türkmen İnanır - MD, Forensic Medicine Specialist, Professor, Uludağ University, Medical Faculty, Forensic Medicine Department, Bursa, Turkey.

ORCID 0000-0002-4047-6455, e-mail: nursel_turkmen@hotmail.com

Murat Serdar Gürses - MD, Forensic Medicine Specialist, Council of Forensic Medicine of Turkey, Bursa Morgue Department, Bursa, Turkey.

ORCID 0000-0002-9982-0476, e-mail: dr.muratgurses@gmail.com

Bülent Eren - MD, Pathologist, Forensic Medicine Specialist, Associate Professor, Tokat Gaziosmanpaşa University School of Medicine, Department of Forensic Medicine, Tokat, Turkey.

ORCID 0000-0002-8296-5484, e-mail: drbulenteren@gmail.com

Ümit Naci Gündoğmuş - MD, İstanbul University, Cerrahpaşa Forensic Medicine Institute, Forensic Medicine Department, İstanbul, Turkey.

ORCID 0000-0001-7981-4725, e-mail: ugundogmus@yahoo.com

Beatrice Ioan - MD, Forensic Pathologist, Professor, Department of Forensic Medicine, Grigore T.Popa University of Medicine and Pharmacy, Institute of Forensic Medicine, Iasi, Romania.

ORCID 0000-0002-0005-9139, e-mail: ioanbml@yahoo.com

\section{References}

1. Reynen K. Cardiac myxomas. N Engl J Med. 1995;333(24):1610-7.

doi: 10.1056/NEJM199512143332407

2. Centofanti P, Di Rosa E, Deorsola L, Dato GM, Patanè $F$, La Torre $M$, et al. Primary cardiac tumors: early and late results of surgical treatment in 91 patients. Ann Thorac Surg. 1999;68(4):1236-41.

doi: 10.1016/S0003-4975(99)00700-6

3. Klima U, Wimmer-Greinecker G, Harringer W, Mair R, Grob CH, Brucke P. Cardiac angiosarcoma - a diagnostic dilemma. Cardiovasc Surg 1993;674-6.

4. Putnam JB, Sweeney MS, Colon R, Lanza LA, Frazier $\mathrm{OH}$, Cooley DA. Primary cardiac sarcomas. Ann Thorac Surg 1991;51:906-10.

doi: 10.1016/0003-4975(91)91003-E
5. Burke AP1, Cowan D, Virmani R. Primary sarcomas of the heart. Cancer. 1992 Jan 15;69(2): 387-95.

doi: 10.1002/1097-0142(19920115)69: 2<387::AIDCNCR2820690219>3.0.CO;2-N

6. Ge Y, Ro JY, Kim D, Kim CH, Reardon MJ, Blackmon S, et al. Clinicopathologic and immunohistochemical characteristics of adult primary cardiac angiosarcomas: analysis of 10 cases. Ann Diagn Pathol. 2011;15(4):262-7.

doi: 10.1016/j.anndiagpath.2011.02.007

7. Simpson L, Kumar SK, Okuno SH, Schaff HV, Porrata LF, Buckner JC, et al. Malignant primary cardiac tumors: review of a single institution experience. Cancer. 2008;112(11):2440-6 doi: $10.1002 /$ cncr.23459 
8. Blackmon SH, Patel A, Reardon MJ. Management of primary cardiac sarcomas. Expert Rev Cardiovasc Ther. 2008;6(9):1217-22.

doi: 10.1586/14779072.6.9.1217

9. Reardon, M.J. and Smythe, W.R. Cardiac Neoplasms. In: Cohn, L.H. and Edmunds, Jr. L.H., eds., Cardiac Surgery in the Adult, McGraw-Hill, New York, 2003.

10. Vander Salm TJ. Unusual primary tumors of the heart. Semin Thorac Cardiovasc Surg. 2000;12:89100.

doi: $10.1053 /$ ct.2000.5080

11. Garcia JM, Gonzalez R, Silva JM, Dominguez G, Vegazo IS, Gamallo C, et al. Mutational status of K-ras and TP53 genes in primary sarcomas of the heart. Br J Cancer. 2000;82(6):1183-5.

doi: 10.1054/bjoc.1999.1060

12. Zu Y, Perle MA, Yan Z, Liu J, Kumar A, Waisman J. Chromosomal abnormalities and p53 gene mutation in a cardiac angiosarcoma. Appl Immunohistochem Mol Morphol 2001;9(1):24-8.

doi: 10.1097/00022744-200103000-00006

13. Kim JS, Song SG, Ko WS, Park YH, Kim JH, Chun $\mathrm{KJ}$, et al. A Case of primary right atrial angiosarcoma manifested with cardiac tamponade. J Korean Soc Echocardiogr. 2004;12:36-8.

doi: 10.4250/jkse.2004.12.1.36

14. Rha SW, Shim WJ, Park SM, Park SW, Lim DS, Kim YH, et al. A Case of Right Atrial Sarcoma Com- plicated with Hemopericardium and Cardiac Tamponade. J Korean Soc Echocardiogr 2002;10:69-73. doi: 10.4250/jkse.2002.10.1.69

15. Herrmann MA, Shankerman RA, Edwards WD, Shub C, Schaff HV. Primary cardiacangiosarcoma: a clinicopathologic study of six cases. J Thorac Cardiovasc Surg.1992;103(4):655-64.

16. Terada T, Nakanuma Y, Matsubara T, Suematsu T. An autopsy case of primary angiosarcoma of the pericardium mimicking malignant mesothelioma. Acta Pathol Jpn. 1988;38(10):1345-51 doi: 10.1111/j.1440-1827.1988.tb02285.x

17. Deetjen AG, Conradi G, Möllmann S, Hamm

CW, Dill T. Cardiac angiosarcoma diagnosed and characterized by cardiac magnetic resonance imaging. Cardiol Rev. 2006 Mar-Apr;14(2):101-3. doi: 10.1097/01.crd.0000174802.61576.5e 18. Meng Q, Lai H, Lima J, Tong W, Qian Y, Lai S. Echocardiographic and pathologic characteristics of primary cardiac tumors: a study of 149 patients. Int J Cardiol. 2002 Jul;84(1):69-75.

doi: 10.1016/S0167-5273(02)00136-5

19. Erpolat OP, Icli F, Dogan OV, Gokaslan G, Akmansu M, Erekul S, et al. Primary cardiac angiosarcoma: a case report. Tumori. 2008 NovDec;94(6):892-7. doi: $10.1177 / 030089160809400624$

Received 26 May 2019; revised 04 June 2019; accepted 15 June 2019.

This is an open access article distributed under the Creative Commons Attribution License, which permits unrestricted use, distribution, and reproduction in any medium, provided the original work is properly cited. 